\title{
'Rudely Interrupted': Shakespeare and Terrorism
}

\author{
GRAHAM HOLDERNESS and BRYAN LOUGHREY
}

On Saturday 19 March, 2005, Omar Ahmed Abdullah Ali tidied his workstation at Qatar Petroleum and shut down his computer for the last time. There were very few people in the office that day, and none of them noticed anything unusual about his behaviour. They recalled him afterwards as 'a decent man', a family man whose wife had, only a month before, given birth to their third child.

Earlier that morning the 38-year old Egyptian computer programmer had said goodbye to Umm Abdullah and his three children quite normally, as if nothing unusual were about to occur. I am not what I am. ${ }^{1}$ Now he left the office quietly, unassumingly, attracting no attention, and went to collect his black Land Cruiser from the company car park. Driving slowly and carefully, he pulled the car onto the road and headed towards the Doha suburb of Fariq Kalaib. ${ }^{2}$

\section{II}

That same Saturday the Doha Players were putting on Twelfth Night in their own theatre in Fariq Kalaib. The production was playing to an audience of around seventy people, including Western expatriates, Palestinians and Lebanese, Eritreans and Somalis, and local Qataris. Previous performances had been praised by the local press as 'lively' and 'fresh'. The production featured a Caribbean setting, and the stage backdrop vibrated with tropical colour. The show was in full swing.

One year before, the Doha Players had celebrated their fiftieth anniversary as an amateur theatrical group. The tiny Gulf state of Qatar (population 840,000, mostly expatriate) is a hive of theatrical 
activity, owing to the diverse population and to strong support from the state, with at least four functioning theatre groups, including a national theatre. The facilities afforded to theatre in the country, all based initially on grants from the ruling royal family, are probably the best in the Middle East. The Doha Players is a largely British and Commonwealth group, which enjoys the support of the local community, including Arab expatriates, as well as the British Ambassador. ${ }^{3}$

The theatre building in which Twelfth Night was being performed was built in 1979. It stood close to the Doha English-Speaking School. Initially the theatre was an out-of-town venue, like Shakespeare's Globe, but the suburbs have grown around it. Adjacent to the theatre stood a hall known as the West End, in nostalgic memory of London's theatre district, and which was used as a tea and coffee bar at intermissions. On the main door of the theatre were carved conventional masks of tragedy and comedy, recognised emblems of theatre throughout the world, and a familiar sight in London's own West End.

\section{III}

In the name of Allah, Most Gracious, Most Merciful, Sawd Al-Jihad presents 'A Letter to the Mujahideen in Iraq':

$\mathrm{O}$ defenders of the religion, brave lions who support words with actions; O those who have fulfilled their promise and given up everything for the sake of Allah: continue in your path of honour. We will not let the crusaders set foot in any place in the land of the prophet Mohammed.

I also command all the brave lions of jihad in Qatar, Bahrain, Oman, the United Arab Emirates and all the countries surrounding Iraq to support you. If every bee stings the pig from a different direction, then he will die from his wounds. O guardians of Islam, stand firm alongside your brothers so that Allah will stand firm next to you. ${ }^{4}$

\section{IV}

The intermission was drawing to a close, and the second half of the play due to start (the performance had been rescheduled by one hour to allow for an earlier finish). The animated and excited audience were ushered into the auditorium to take their seats. 


\begin{abstract}
Enter VIOLA, and CLOWN with a tabour.
VIOLA: Save thee, friend, and thy music: dost thou live by thy tabour?

CLOWN: No, sir, I live by the church.

VIOLA: Art thou a churchman?

CLOWN: No such matter, sir: I do live by the church; for I do live at my house, and my house doth stand by the church.

VIOLA: So thou mayst say, the king lies by a beggar, if a beggar dwell near him; or, the church stands by thy tabour, if thy tabour stand by the church.

CLOWN: You have said, sir. To see this age! A sentence is but a cheveril glove to a good wit: how quickly the wrong side may be turned outward! (III.i.1-13)
\end{abstract}

Omar Ahmed Abdullah Ali stopped his car within view of the theatre. He could see the building, the theatre and its annex, the breeze-block perimeter wall and cars parked in a defensive circle around it. $\mathrm{He}$ could see the steps leading up to the door of the theatre. There were no sentries or guards, no additional security, no locked doors. There was a gap in the ring of cars wide enough for him to get through. ${ }^{5}$

Throughout the long, slow drive he had felt numb, detached, a man sidelined by the enormity of his own mission. Even the thought of the explosives with which the car was packed had caused him no particular concern. Now, as the moment approached, he began to feel anxious. His palms sweated on the steering wheel. Unwelcome images came to mind, pictures of wife and children, distractions. He focused, as he had been trained to do, on the objective of the action. We will not let the crusaders set foot. There will not be any safe passage. 'We promise to introduce them to the word terror over and over again, and they will try and translate it into all their languages. ${ }^{6}$

He eased the car into forward gear. 'Allah made us promise. Forsake everything in his cause, and for the sake of your victory'. ${ }^{7}$ His grip tightened on the wheel. He floored the accelerator and sped towards the breeze block wall. The big car crashed through the wall, scattering dust and debris, and roared towards the steps of the theatre entrance. 'God is great. God is great. Brave lions of jihad'. The car hit the steps with a bang, and the chassis grounded on the concrete. Desperately Omar tried to accelerate forward to drive into the building, but the wheels spun helplessly. The engine screamed. 
The play's director, teacher and amateur actor Jonathan Adams, was sitting in the control room at the back of the theatre watching the performance. From outside he heard a bang and the sound of an engine running at high speed. Something was going on in the car park. The noise would disturb the performance. He went to the door to see what the commotion was all about. Omar saw Jonathan appear at the top of the steps. The mission was in jeopardy. 'Be clamorous, and leap all civil bounds/Rather than make unprofited return'. ' God is great'. He triggered his explosives. Jonathan took the full force of the blast and was blown back into the theatre, probably killed instantly. The suicide bomber also died. Twelve other people were injured, including six Qataris, a Briton, an Eritrean and a Somali, none seriously.

The impact of the "massive explosion" was heard and felt inside the auditorium. Kerry Ruek, playing Feste, was blown from the stage in mid-speech. He remembers, with characteristic understatement, the performance being 'rudely interrupted' ${ }^{10}$ The sound and lighting engineers were blown out of the control room. Everything went dark. There was smoke everywhere, things were flying through the air. It was pandemonium. ${ }^{11}$

A gas explosion was suspected. Members of the Players quickly gathered children together to evacuate them. People streamed from the building.

Outside what had happened was all too obvious. Nearby buildings had been extensively damaged. The windows of the school were all shattered. Cars were burning in the car park. People had been blown off their feet and were seen lying on the ground. ${ }^{12}$ The body of Jonathan Adams lay inside the ruined theatre entrance. His wife Rosemarie was the first to reach him. Kerry Ruek tried desperately to revive him, but to no avail. ${ }^{13}$

As the car had been tilted at an angle on the steps, the force of the explosion blew backwards and demolished the theatre annex. If the play had not been rescheduled, the annex would have been filled with members of the audience enjoying their interval tea and coffee. ${ }^{14} \mathrm{Had}$ the mission gone according to plan, casualties would have been much higher. Instead, by luck and misjudgement, the terrorist succeeded in inflicting a few nonfatal wounds, and killing only himself and Jonathan Adams. In an instant, comedy had turned to tragedy. The theatre doors, with their comic and tragic masks, lay where they had been hurled among the building's wreckage. 'How quickly the wrong side may be turned outward'. 


\section{VI}

Qatar is a relative stranger to terrorism, though there are many reasons why it could be ranked as a prime Al-Qa'eda target. Qatar hosted the U.S. Central Command's operational headquarters from early 2003, after it was shifted from Saudi Arabia, thus forming a bridgehead for the occupation of Iraq. The Al Saliya camp on the outskirts of Doha, only twelve miles from the theatre, houses two thousand U.S. troops. The U.S. Embassy was formerly located in the area occupied by the theatre, but now stands some six miles away. On 14 March 2005, days before the bombing, the U.S. State Department had issued a general warning to all its citizens travelling in the Gulf that 'extremists may be planning to carry out attacks against Westerners and oil workers' in the region. The Doha atrocity occurred on the second anniversary of the invasion of Iraq (launched on 20 March 2003).

Conversations with the survivors of the attack indicate that at the time there was no particular awareness on the part of the Doha Players or their audience of any serious or imminent terrorist threat. Qatar had not seen this kind of violence before, and was thought of as very safe. No-one had even noticed the significance of the date.

More significantly, the Players could see no rationale for an attack on them, their audience and their theatre. It is difficult for them to see what they do as in any way controversial. They are not a military or political organisation, and did not think of themselves as having any high-profile symbolic value. They see themselves as a diverse Qatari expatriate community, not an outpost of Western civilisation. They have no strong U.S. affiliation. They do nothing to antagonise local sentiments, serve no alcohol and conform obediently to the state's byzantine censorship regulations. They are sceptical about any antitheatrical motivation deriving from Islamic dislike of drama, since there are also local theatre groups (Qatari Group Theatre and Gulf Group Theatre) as well as a national theatre. ${ }^{15}$

But targeted they were, and allegedly by Jund Al-Sham, the group which claimed responsibility for the attack. Only a few days before, an audio recording posted on an Islamist website, purporting to contain the voice of Saleh Mohammed Al-Aoofi, Al-Qa'eda's commander in Saudi Arabia, suggested to intelligence analysts that a new phase of global terrorist organisation might well be in the process of Please check spelling of fhis name formation. Al-Aoofi was paying homage to Musab Al-Zaqarwi as throughout the heir apparent to Osama Bin Laden. Jund Al-Sham was the name 

that its operations would be extended from insurgency in Iraq to Al this name Qa'eda's territory of global jihad. The former French defence official throughout Alexis Debat writes:

Last week's bombing in Doha may signal the beginning of that phase. Even though very little is know at this point about the Egyptian computer expert who exploded his car next to the Doha English-Speaking School, Jund Al Sham's comeback on the global scene in a country so remote from its initial area of operation seems to validate a number of developments recently picked up by US and Iraqi intelligence services. This information is increasingly interpreted as indicating that Zarqawi has emerged as the most important operational leader of the global jihad and even a possible replacement to bin Laden as the figurehead of the movement. ${ }^{16}$

Shakespeare and jihad no longer appear such improbable bedfellows. The Doha Players may have served as a soft civilian target, like the Soho nightclub recently threatened by a failed car-bomb in London. They may have represented a random gathering of Westerners and their associates, like the occupants of Glasgow Airport, who recently narrowly escaped violence from another grounded car-bomb. But it is far more likely, surely, that they represented what Jurgen Habermas calls a 'symbolically suffused' objective, ${ }^{17}$ one that brought together a loaded matrix of meanings: the English language; Western culture; Christian civilisation. These familiar terms, for the fundamentalist, translate as the foreigner; the infidel; the crusader. And in this instance all these figures were represented by the name of Shakespeare.

\section{VII}

The Doha Players responded to this event with shocked innocence. Such candour may seem in retrospective analysis naïve, but God forbid that we should ever lose the capability of innocence, or the right of innocence to be shocked. Derrida was grasping at some such imperative when he spoke of $9 / 11$, insisting on the absolute necessity of

compassion for the victims and indignation over the killings. Our sadness and condemnation should be without limits, unconditional, unimpeachable ... they respond with what might be called the heart and they go straight to the heart of the event. ${ }^{18}$ 
But Shakespeare is clearly inseparable from, indeed almost synonymous with, the Anglo-American Western culture that is identified (and not only by fundamentalists) with the Israel/Palestine problem, with the invasions of Afghanistan and Iraq, and with a global cultural dominance inimical to Islam. Derrida again:

The world order ... targeted through this violence is dominated by the Anglo-American idiom, an idiom that is indissolubly linked to the political discourse that dominates the world stage, to international law, to diplomatic institutions, the media, and the greatest technoscientific, capitalist and military power. ${ }^{19}$

The Shakespeare of postcolonial criticism is often presented as an instrument of oppression. Postcolonial critics have shown how, over the previous two centuries, Anglo-American criticism consolidated an imperial Shakespeare, one whose works testified to the superiority of the civilised races and could be used to establish and maintain colonial authority. ${ }^{20}$ Shakespeare represents the crowning glory of the English language, but the history of how that language was extended from a parochial island tongue into the world language of one thousand million masks a much more violent process involving subjugation of native peoples, extirpation or annexation of native cultures, and the imposition through administrative and educational systems of Anglocentric norms and ideologies.

The various forms of colonial response have been well studied and well documented. Some subjugated cultures engaged in imitation and mimicry, assisting the domestication of the foreign power. Elsewhere native intellectuals challenged colonial culture in favour of their own native literatures, initially by exposing the conscious or unconscious racist content of imperial fictions, as when Chinua Achebe declared that Joseph Conrad was 'a bloody racist'. ${ }^{21}$ Dramatists in the former colonies began to reread Shakespeare from a colonised viewpoint. Postcolonial criticism also re-evaluated the early modern period in which empire had its origins, and demonstrated that colonial discourse was no mere passive backdrop to Shakespearean drama but rather one of its key discursive contexts. ${ }^{22}$ In other words, these plays were immersed in the formation of empire before they became its tools, 'entangled from the beginning with the projects of nation-building, empire and colonization'. ${ }^{23}$ 
This is the Shakespeare referred to by the United Press International editor, Martin Walker, writing of the Doha bombing; the Shakespeare who

stands for the Western invasion of Islam's holy peninsula. He is the symbol of the English language that he helped perfect, and thus he also symbolizes its steady advance into the mouths and sensibilities of a generation of educated Arabs. ${ }^{24}$

\section{VIII}

In Twelfth Night innocence is constitutive and foundational: the play 'dallies with the innocence of love,/Like the old age'. (II.iv.47-8) But in the context described above it becomes harder to view a performance of Twelfth Night, in Qatar, on the second anniversary of the invasion of Iraq, as harmlessly innocent. It was of course exactly that, within the values of the liberal democratic culture the play itself embodies, and the Doha Players espouse. But to Omar Ahmed Abdullah Ali, and to those who trained and equipped him, it must have represented something much more inimical and provocative: a flagrant display of Western cultural power. It is still possible to recall, though only as a faint echo from an 'old age', that celebration of Twelfth Night as a kind of prelapsarian festivity:

Twelfth Night ... is filled to the brim and overflowing with the spirit that seeks to enjoy this world without one thought or aspiration beyond. It jumps the hereafter entirely. ${ }^{25}$

A strict Muslim like Omar, taught from the very beginning of the Holy Quran to 'have faith in the Hereafter', ${ }^{26}$ would have had no illusions about being able to jump the life to come, and no sympathy for anyone who thought they could.

There are those who do think, because they are virtuous, "there shall be no more cakes and ale' (II.iii.114-5). If the play were nothing but cakes and ale, we too would be seeking elsewhere for the location of the virtuous; but it is not. Twelfth Night is not known to modern criticism as a simple celebration of fun-filled epicureanism. In fact it has been understood in completely the opposite way, as a wry reflection on the shallowness of irresponsible gaiety. W.H. Auden saw Shakespeare here in a mood of 'puritanical aversion' from the 
'pleasing illusions of life'; and Jan Kott thought it a 'bitter comedy about the Elizabethan dolce vita' ${ }^{27}$ To these critics, and to many others, the undertones of sadness, nostalgia and disillusion that haunt the play suggest an atmosphere of disenchantment and distaste for thoughtless pleasure. Sir Toby is 'sure care's an enemy to life', but the play does not for one moment fall into the illusion that responsibility, 'care', can be ignored or set aside. In interpretations such as these, Malvolio becomes a serious witness to the conscience of the age, and a precursor of the Puritan Commonwealth.

Malvolio, 'a kind of Puritan' (II.iii.140), rejects the epicurean dolce vita as vehemently as did Jawad Akbar and Omar Khyam, who plotted to blow up London's Ministry of Sound nightclub. ${ }^{28}$ Malvolio sees himself as the natural heir to the household authority, and longs to be in a position where he can extirpate what he sees as riotous behaviour. He is tricked into making a fool of himself, and detained as a madman. He is 'propertied' (IV.ii.94), treated as an object without human rights. He is imprisoned in a dark cell ('they have laid me here in hideous darkness' [IV.ii.30]), and subjected to forms of torture such as sensory deprivation ('They ... keep me in darkness ... and do all they can to face me out of my wits' [4.2.94-6]). ${ }^{29} \mathrm{He}$ feels that he has been 'abused' ('there was never man so notoriously abused' [IV.ii.90]), and his employer Olivia, having heard his story, is bound to agree: 'he hath been most notoriously abused' (V.i.380) ${ }^{30}$ To those who trick and torment him, all this is legitimate amusement. Olivia apologises to Malvolio, and the Duke commands Fabian to 'pursue him, and entreat him to a peace'. (V.i.379) But the last words uttered by Malvolio on stage suggest that he will not be so easily entreated to a 'peace' on others' terms: 'I'll be revenged on the whole pack of you!' (V.i.377). These are not words calculated, like the fake letter of challenge, to 'breed no terror'. (III.iv.190) They were never spoken on stage on 19 March 2007, as Omar Ahmed Abdullah Ali had successfully brought home his revenge against the whole pack of them. Terror was already breeding, already bred.

\section{IX}

Twelfth Night ends with restoration, reconciliation and unity. The lost are found. Misunderstanding is cleared up, identity restored: 'Cesario' can turn her assumed masculine disguise inside out to reveal 
her true feminine self. The comic subplot is disclosed and Malvolio released from his bondage. The members of the cast are largely organised into heterosexual couples (Viola/Orsino, Olivia/Sebastian, Sir Toby/Maria), so the convention of marriage is employed to realign the characters into an orderly configuration, free from disguise, transsexual relationship and misapprehension:

When ... golden time convents,

A solemn combination shall be made

Of our dear souls (V.i.381-3).

But the play does not actually end with this 'solemn combination', but with an isolated individual, and with a song. Feste's valedictory ballad is a melancholy little reflection on the intrinsic unhappiness of endings. Looking back to childhood, he recalls a time when 'play' was innocent and unproblematic: when pranks and folly needed no justification, being acceptable as innocuous fun appropriate to the status of a child - 'A foolish thing was but a toy' (V.i.388). For the adult however, all that has changed: the irresponsibility of folly in a grown man is regarded as unacceptable, threatening and subversive; the adult who wants to continue playing games is regarded as a criminal and excluded by authority from civilised society, displaced to the margins of social life - 'Gainst knaves and thieves men shut their gates' (V.o.392). Adulthood marks an end to the liberated irresponsibility of play.

'I am sure', Sir Toby affirms, 'care's an enemy to life' (I.iii.2). Yet the song with which the play closes seems to confirm that 'care' is the very condition of 'life'; and that to be 'careless' is not to be 'carefree', but to be engaged in a continual, hopeless effort to keep the inevitability of anxiety at a distance. Is life then its own enemy, self-divided against its own deepest and most passionate needs? Are play and pleasure locked into an irreconcilable antagonism with the anxiety that threatens them?

The one character who professes belief in the necessity of anxiety is the one character who is excluded from the otherwise universal harmony of the play's conclusion. Malvolio, bitterly disillusioned and 'notoriously abused' (V.i.376), has excluded himself from the compact of cheerfulness and gaiety secured by the rest of the cast. Possessed by a vindictive rage, he unites both those who have fooled him and those to whom his own folly has been exposed, in a comprehensive passion of indignation: 'I'll be revenged on the whole pack of you!' (V.i.375). 
He places himself outside the newly integrated community of the play, and casts a shadow over its delicately achieved balance of concord and reconciliation which, we recognise, has been attained only at the cost of ejecting an inassimilable fragment. Even in his absence, his painful alienation and his oath of vengeance brood ominously over the play's closure; and there at the margins of the drama, his bitter and disappointed presence seems to meet the chastened resignation of the Clown, stranded alone with his own melancholy music, evidently no more a part of the collective celebrations than is Malvolio himself. ${ }^{31}$

But if care truly is both life's implacable enemy and life's inescapable antagonist, then Malvolio can be regarded as a central figure in the play. His fate is to be duped with false hopes and tempted with illusory aspirations; to experience disillusion and disenchantment: and finally to be diagnosed as mad, bound, confined and eventually released to endure the open mockery of his captors and the suppressed amusement of his superiors. ${ }^{32}$ In the light of Feste's song, and of the ambivalent nature of the play's 'happy ending', Malvolio can obviously stand as a representative figure in that inhospitable world where even innocent folly is punished and excluded. He is of course a victim of poetic justice, since he was a self-appointed instrument of that universal anxiety, dedicated to the identification of folly in others and the systematic denial of folly in himself. Yet although foolishness, irresponsibility and the hopeless pursuit of perpetual pleasure are all common characteristics - they are certainly central to the character of Orsino, and Olivia is not free from them - Malvolio is the only character to be punished for his participation in a common destiny. He is the scapegoat, the victim who bears away with him the sins of the community.

Perhaps the ritual is only a game, and Malvolio may be entreated back to join the party. Or perhaps not. As the Clown stands alone, outside the official revelling of a united court, looking towards a disenchanted world where the rain rains every day, Malvolio's threat of revenge may begin to assume a shadowy substance and a menacing shape, haunting the Western secular dream of materialist freedom. Those who invest their existence in the expectation of perpetual pleasure, guaranteed happiness, the uninterrupted continuance of the game, will always be exposed to the resentment and resistance of those acquainted with anxiety. Although Malvolio is no historical portrait of a puritan, it remains a tempting possibility (pursued by some stage productions) that his banishment and threatened revenge may correspond to the 
marginalisation and eventual victory of the puritans who were later to fight against the king in the English Civil War.

The fact that on that night in Doha Malvolio did not get the chance to utter his desire for vengeance in words, since another vengeance had already been taken in deed, measures the real cultural damage done by Omar's suicide bomb. For Malvolio is inside the play, and his voice is there to be heard alongside the voices of those who abuse him. The harsh discordance of his cry for revenge, and the long shadow he casts over the play's final reconciliation, are left as characteristically jarring notes in Shakespeare's sweet but polyphonic music. The difficulty of maintaining community in such circumstances is not shirked, but confronted and handed over to the audience as a problem of interpretation. Twelfth Night is not a childlike celebration of innocuous play, but a mature and complex drama which explores the conflict between a playfulness that can offend, and a carefulness that can threaten play. Malvolio's anguish must be heard; but equally the community of the play's world must find some road to peaceful coexistence. Ultimately the play appeals to justice via a simple notion of fairness which can go very deep, and can form a ground of truth and reconciliation between people who have all suffered enough, if that the injuries be justly weigh'd, that have on both sides pass'd (V.i.366-7).

\section{$\mathbf{X}$}

How far had Twelfth Night travelled to reach its Caribbean setting in the Doha Players Theatre? Not very far at all, in fact. Traditional nationalistic and newer historicist interpretations locate it somewhere between the paradigmatic 'English country house' and the nowhere of romance. That the play belongs on some kind of borderline is often acknowledged, but this is not thought of geographically, but rather as the border between reality and fantasy, or 'the borders of wonder and madness'. ${ }^{33}$

'Illyria' is usually either nowhere in particular, or the Adriatic coast of Greece. Thus the play is often thought to combine its Englishness with a Graeco-Roman ambience. Illyria was in fact somewhere in the Western regions of the Balkan Peninsula, on the coastline now occupied by Croatia, Montenegro and Albania. In the eastern regions of Europe, then, and on a significant borderline between West and 
East. In Shakespeare's time this region was a critical border, since it hinged Christian Europe to the Islamic Ottoman Empire. ${ }^{34}$ In one of the play's sources, Barnabe Riche's Riche His Farewell to Militarie Profession (1581), the Duke has 'spent a yeres service in the warres against the Turke' ${ }^{35}$ In Twelfth Night, there are references to the Shah of Persia: Fabian talks of a pension 'from the Sophy' (II.v.181), and Sir Toby pretends that Viola has 'been a fencer to the Sophy' (III. iv.284). These references probably derived from published accounts of Sir John Shirley's travels and adventures in the Levant. Shirley acted as a kind of ambassador to the Shah in visits to Moscow, Prague and Rome. Maria describes Malvolio's smile as containing 'more lines than is in the new map with the augmentation of the Indies'. (III. ii.75-7) The reference is to a map published in 1599 that gave greater prominence to the East Indies. And just as Othello associates himself both with the 'turbaned Turk' and the loyal Venetian who kills him, so Orsino, preparing to sacrifice Viola on the altar of his jealous passion, presents himself as a legendary 'Egyptian thief' (V.i.116) who tried to kill the thing he loved.

The world of the play is then at some considerable distance from England, and is large enough to encompass allusions to the Islamic world, to Persia and the Ottoman Empire. We may think of Shakespeare as almost synonymous with an Anglophone culture of empire, as Michael Neill puts it: 'Our ways of thinking about such basic issues as nationality, gender and racial difference are inescapably inflected by his writing'. ${ }^{36}$ Yet here we see Shakespeare setting his play on the border between West and East, Christianity and Islam, and opening doors to both. Today it is manifest that the Shakespeare once dispersed by linguistic imperialism around the globe is also a Shakespeare wholly or partially 'hybridised' by contact with other languages and cultures. As Dennis Kennedy puts it, 'almost from the start of his importance as the idealized English dramatist there have been other Shakespeares, Shakespeares not dependent on English and often at odds with it' ${ }^{37}$ Shakespeare in short 'goes native' every time he crosses a geographic or national border, and 'may thus be construed as the repositioned product of a complex of social, cultural and political factors that variously combine under the pressure of colonial, postcolonial and more narrowly national imperatives'. ${ }^{38}$ 


\section{XI}

The objective of terrorism is to terrorise. In the case of the Doha bombing, the point seems to have been to scare expatriate workers into leaving Qatar. ${ }^{39}$ The Doha players were certainly frightened by the attack, and they testify to a sense of anxiety and suspicion not previously present in their everyday lives. But they have no intention of leaving Qatar, or of abandoning their interest in theatre. On the contrary, the atrocity has brought them closer together into a selfhelp group dedicated to rebuilding the ruined theatre as a testament to Jonathan Adams. The campaign to raise the funding took some time to build momentum, but took off when students of the Qatar Academy raised 152,000 Qatari Riyal (QR) in memory of their admired and much missed teacher by means of a cultural festival. This was supplemented by a grant of more than 8 million QR from His Highness the Emir Sheik Hamad bin Khalifa Al-Thani. The Qatar Foundation Vice-President for Education, Dr Abdulla Al-Thani, celebrated the way in which students 'channelled their shock and grief into a fundraising effort in memory of their teacher' ... They will defend our society against intolerance, and they will be the guardians of our nation's civilised values'. 40 'My words are ... full of peace' ${ }^{41}$ The Chairman of the Doha Players, Kerry Ruek, said:

The rebuilding of the theatre will leave a lasting legacy for the community in memory of Jon. The new theatre will stand as a message of peace and understanding among all peoples of the world.

Dave Garrod, a member of the theatre board, is quoted as saying that the new theatre would be named 'The Phoenix'. ${ }^{42}$ If so, the name is beautifully appropriate. The legend of the Phoenix is Egyptian in origin, the sacred firebird of ancient mythology, but it was adopted by Christians and became a figure for the self-immolation and resurrection of Christ. Shakespeare's poem 'The Phoenix and the Turtle' locates the scene in Arabia: 'Let the bird of loudest lay / On the sole Arabian tree ...'. Thus Eastern and Western traditions in this emblem lie reciprocally enfolded in a 'mutual flame'. Jonathan Adams and the theatre he loved perished together. But a new theatre will rise from the ashes of the old, and preserve his memory, let us hope, 'to eternity'. ${ }^{43}$ 
Which edn

is used

here? If

Notes

Please give full names of editors

1. William Shakespeare, Twelfth Night, III.i.143. All references are to the Arden Shakespeare edition, edited by J.M. Lothian and T.W. Craik (London: Methuen, 1975, repr. 2007).

2. This is a reconstruction based on the known facts. See 'Bomber Identified as Egyptian', The Peninsula, 21 March 2005; 'Egyptian Bomber Blamed for Qatar Attack', Breaking News, 20 March 2005, available at $<<$ http://www.ireland.com/newspaper/ breaking/2005/0320/breaking9.html $>>$ (Accessed 30 July 2007); 'Protest Rally Over Qatar Bombing', BBC News, 21 March 2005, available at <<http://news.bbc.co.uk/1/hi/world/ middle_east/4368267.stm $>>$ (Accessed 30 July 2007).

3. Details are derived from conversations between Bryan Loughrey and members of the Doha Players, March 2007.

4. Extracts from Saleh Mohammed Al-Aoofi, 'Audio Statement from Al-Qa'eda in Saudi Arabia to Abu Musab Al-Zarqawi in Iraq'. This taped speech 'according to US intelligence officials, gave a green light to the Doha bombing'. Alexis Debat, 'The New Head of Jihad Inc.?', CBS News, 17 March 2005, available at $<<$ http://www.cbsnews.com/ stories/2005/03/17/terror/main681331.shtml?source=search_story $>>$ (Accessed 26 July 2007).

5. This is based on recollections from Kerry Ruek, Chair of the Doha Players, in conversation with Bryan Loughrey, March 2007.

6. Extracts from Al-Aoofi, 'Audio Statement from Al-Qa'eda'.

7. Ibid.

8. Twelfth Night, I.iv.21-2.

9. U.S. Army Captain Eric Clark, quoted in 'Egyptian Bomber Blamed for Qatar Attack', Breaking News, 20 March 2005, available at $<<$ http://www.ireland.com/newspaper/ breaking/2005/0320/breaking9.html $>>$ (Accessed 30 July 2007).

10. Kerry Ruek in conversation with Bryan Loughrey.

11. These are words of Julie Hirst, quoted BBC News, 21 March 2005, available at $<<$ http://www.cbsnews.com/stories/2005/03/17/terror/main681331.shtml? source=search_ story $>>$ (Accessed 26 July 2007).

12. Ahmed Goudah, quoted in 'Egyptian Bomber Blamed for Qatar Attack', Breaking News, 20 March 2005, available at $<<$ http://www.ireland.com/newspaper/ breaking/2005/0320/breaking9.html >> (Accessed 30 July 2007).

13. Details derived from conversations between Bryan Loughrey and members of the Doha Players, March 2007.

14. Gerard Kennedy, quoted in 'Bomber Identified as Egyptian', The Peninsula, 21 March 2005.

15. Details are derived from conversations between Bryan Loughrey and members of the Doha Players, March 2007.

16. Debat, 'The New Head of Jihad Inc.?'. Al-Aoofi was killed by Saudi police in Medina in August 2005. See CBS News, 18 August 2005, available at $<<$ http://www.cbsnews. com/stories/2005/08/18/terror/main784447.shtml > (Accessed 26 July 2007).

17. Jurgen Habermas, quoted in Giovanni Borradori, Philosophy In a Time of Terror: Dialogues With Jurgen Habermas and Jacques Derrida (Chicago: Chicago University Press, 2003), 25.

18. Jacques Derrida, quoted in Borradori, Philosophy In a Time of Terror, 87. the most

recent,

please

present

as: 2007

[1975]. 
19. Ibid., 100 .

20. Ania Loomba and Martin Orkin, eds, Post-colonial Shakespeares (London: Routledge, 1998), 1.

21. Chinua Achebe, 'An Image of Africa: Racism in Conrad's Heart of Darkness', in Hopes and Impediments: Selected Essays 1965-1987 (Oxford: Heinemann, 1988). p. 8

22. Francis Barker and Peter Hulme, "Nymphs and Reapers Heavily Vanish": the Discursive Con-texts of The Tempest', in Alternative Shakespeares, ed. John Drakakis (London: Methuen, 1985), 198.

23. Michael Neill, 'Postcolonial Shakespeare? Writing Away From the Centre', in Loomba and Orkin, eds, Post-colonial Shakespeares, p. 168. Please give name of publication and full

Walker, 'Why They Bomb Shakespeare', 2005, available at $<<$ http://www. in print Please give washtimes.com/upi-breaking/20050320-034942-5213r.htm >> (accessed 26 July 2007).

forename(s) 25. H.J. Ruggles, quoted in Lothian and Craik, eds, Twelfth Night, lii.

in full 26. The Koran, trans. Arthur J. Arberry (Oxford: Oxford University Press, 1983), 2.

27. Auden and Kott are quoted in Lothian and Craik, eds, Twelfth Night, liv.

28. Akbar said they would not be blamed for killing innocent people at the club, as they were targeting only 'slags dancing around'. 'Gang "Planned to Blow Up London Nightclub"', The Guardian, 25 May 2006, available at $<<$ http://www.guardian.co.uk/ terrorism/story/0,1783239,00.html?=rss $>>$ (Accessed 26 July 2007).

29. See David Carnegie, "Maluolio Within": Performance Perspectives on the Dark House', Shakespeare Quarterly 52.3 (Autumn 2001), 393-414.

30. 'Abuse' is the term commonly used to describe the torture and humiliation of detainees in the notorious Abu Ghraib military prison in Iraq.

31. See Yu Jin Ko, 'The Comic Close of Twelfth Night and Viola's Noli Me Tangere', Shakespeare Quarterly 48.4 (Winter 1997), 391-405.

32. See Allison P. Hobgood, 'Twelfth Night's "Notorious Abuse" of Malvolio: Shame, Humorality and Early Modern Spectatorship', Shakespeare Bulletin 24.3 (September 2006), $1-22$.

33. Frank Kermode, quoted in Lothian and Craik, eds, Twelfth Night, 1v.

34. In the 1590 s the Turks were launching major campaigns in Hungary.

35. Quoted in Lothian and Craik, eds, Twelfth Night, 157.

36. Neill, 'Postcolonial Shakespeare?', 184.

37. Dennis Kennedy, Foreign Shakespeare (Cambridge: Cambridge University Press, 1993), 2.

38. Thomas Cartelli, Repositioning Shakespeare: National Formations, Postcolonial Appropriations (London: Routledge, 1999), 1.

39. 'The bombing appeared to be directed against Qatar's pro-western policies and at frightening expatriate workers'. The Guardian, 21 March 2005, available at $<<\mathrm{http}: / / \mathrm{www}$. guardian.co.uk/uk_news/story/0,3604,1442412,00.html >> (Accessed 30 July 2007).

40. Qatar Foundation News, 11 October 2006, available at $<<$ http://www.qf.edu.qa/ output/page1404.asp>> (Accessed 30 July 2007).

41. Twelfth Night, I.v.213.

42. 'Tributes to Man Who Took Full Force of Blast', The Times, 21 March 2005.

43. William Shakespeare, 'The Phoenix and the Turtle', in William Shakespeare: the Complete Works, ed. Stanley Wells and Gary Taylor with John Jowett and William Montgomery (Oxford: Oxford University Press, 1988), 782. In Twelfth Night (V.i.159), a 
play in which more than one new person rises from the ashes of the old, the vessel stolen by Antonio is called the Phoenix. 